\title{
THE EFFECT OF THE SYSTEM OF CROSSING ON FATTENING PARAMETERS OF WEANED LAMBS
}

\author{
D. Ružić-Muslić ${ }^{1}$, M. P. Petrović ${ }^{1}$, M. M. Petrović ${ }^{1},{ }^{1}$ Z. Bijelić, $^{1}$ V. \\ Pantelić $^{1}$, P. Perišić ${ }^{2}$, V. Caro-Petrović ${ }^{1}$ \\ ${ }^{1}$ Institute for Animal Husbandry, Belgrade-Zemun, 11080, Srbija \\ ${ }^{2}$ Faculty of Agriculture University of Belgrade, Nemanjina 6, 11080 Belgrade, Republic of Serbia \\ Corresponding author: muslic.ruzic@.gmail.com \\ Original scientific paper
}

\begin{abstract}
In this paper, the effect of different systems of crossing of sheep: two-breed (PxW) and three-breed (PxWxIDF) on production results - body weight and average daily gain of lambs weaned at the age of 60 days and fattened to age of 120 days, was investigated. Also, the effect of crossing on consumption and conversion of food and nutrients was monitored. Study was carried out on the Experimental sheep farm of the Institute for Animal Husbandry, Belgrade-Zemun, and following breeds were used in the crossing: Pirot Pramenka (P), Wurttemberg (W) and Ile de France (IDF). Pirot Pramenka was used as the maternal basis, while Wurttemberg rams were used as sires, and as terminal breed, Ile de France rams were used. Results have shown that the three-breed crosses of $\mathrm{F}_{1}$ generation, compared to two-breed crosses, obtained higher body gain for $19.23 \%$ with lower food intake for $5.19 \%$, during fattening period lasting from 60th to 120th day of age. Regarding feed conversion ratio, they used per $1 \mathrm{~kg}$ of body gain $29.61 \%$ less hay and $20.82 \%$ less concentrate feeds. Positive biological effect exhibited in three-breed crosses (PxWxIDF) is consequence of individual heterosis and maternal heterosis.
\end{abstract}

Key words: crossing, gain, body mass, feed conversion, heterosis

\section{Introduction}

Application of crossing in sheep production is aimed at increase of meat production and it is very important in programs of improvement of sheep breeding. Crossing of different sheep breeds is focused on use of the superiority of specialized sheep breeds with good meat production and transmitting of desirable genes to their progeny (Farid, 1991; Schoeman, 1995; Petrović, 2000, Chrestha and Heaney, 2004). Success in crossing, in addition to genetic difference between crossed populations, greatly determined the system of crossing. 
In the system of crossing which includes only two breeds only the heterosis of the individual animal is utilized, whereas in three-breed crossing the heterosis of dam is added. Full utilization $(100 \%)$ of the heterosis of the individual animal as well as the dam results in higher gain and body mass, compared to two-breed crosses. Use of rams of Ill de France breed as terminal breed caused increase of body mass in their progeny by $12 \%$, compared to results obtained for rams of original breed (Boujenane et al, 1998).

Petrović et al. (1995), in the study of the effects of various crossing combinations: Pirot Pramenka x Merinolandschaf, Pirot Pramenka x Ile de France, Pirot Pramenka x Merinolandschaf x Ile de France and Pirot improved sheep x Ile de France, in the period to weaning (90 days of age), have determined that threebreed crosses used by $17.40 \%$ less concentrated food per kilogram of gain, compared to two-breed crosses.

Objective of present study was to compare production performance of lambs-crosses of $F_{1}$ generation: Pirot Pramenka $x$ Wurttemberg and Pirot Pramenka $\mathrm{x}$ Wurttemberg $\mathrm{x}$ Ile de France, weaned at the age of 60 days and fattened to the age of 120 days.

\section{Material and methods}

Study was carried out on the Experimental sheep farm of the Institute for Animal Husbandry, Belgrade-Zemun. In the research, 60 lambs - crosses of $F_{1}$ generation were used: Pirot Pramenka $x$ Wurttemberg (I) and Pirot Pramenka $x$ Wurttemberg x Ile de France (II), weaned at the age of 60 days. All animals were equal in regard to body weight age and sex/gender (gender ratio 1:1). Initial body weight of lambs at the beginning of trial was around $18.0 \mathrm{~kg}$.

Nutrition of lambs with forage mixtures was ad libitum, whereas the quantity of hay was limited and equally distributed to groups. The nutritional value was calculated according to the French system recommended by INRA (1988) and Obračević (1990). Structure and nutritional value of used mixtures is presented in Table 1.

Changes of the body weight average daily gain, consumption and conversion of food and nutrients were checked in 15 day intervals, whereas the initial and final body weights were measured three times in three consecutive days. Statistical processing of obtained data was done using the program Stat.Soft, Inc (2003) STATISTICA (data analysis software system), version 6, by applying standard mathematical-statistical methods. 
Table 1.Structure and nutritional value of concentrate mixture used in nutrition of weaned lambs, \%

\begin{tabular}{|l|c|}
\hline Feeds & $\%$ \\
\hline Corn & 73 \\
\hline Sunflower meal & 23 \\
\hline Lime & 1 \\
\hline Salt & 1 \\
\hline Premix & 870 \\
\hline Dry matter, g kg- ${ }^{1}(*)$ & 7.51 \\
\hline NEM,MJ $(*)$ & 0.99 \\
\hline UFV(**) & 142 \\
\hline Total protein,g/kg(*) & 43 \\
\hline RUP & 102 \\
\hline PDIN/g/animal/day $(* *)$ & 102 \\
\hline PDIE/g/animal/day $(* *)$ & 8.4 \\
\hline Ca,g(*) & 4.6 \\
\hline P,g $(*)$ & \\
\hline
\end{tabular}

RUP_rumen non-degradable protein; PDIN - protein digested in small intestine depending on the fermenting nitrogen; PDIE - protein digested in small intestine depending on the fermenting organic matter

$* *$ INRA (1988)

*Obračevic (1990)

\section{Results and Discussion}

Indicators of the body mass and realized daily gain are presented in Table 2. It is known that the body mass is the most relevant factor influencing the carcass value (Rodriguez, 2011). It can be observed in the table that lambs obtained in three-breed crossing, compared to two-breed crosses, had higher body weight at the end of the fattening by $2.82 \mathrm{~kg}$ or $8.76 \%$. By statistical procedure it was determined that the system of crossing had very significant effect on body weight $(\mathrm{P}<0.01)$.

In regard to average daily gain of trial lambs, from weaning to age of 120 days, it was established that three-breed crosses had higher gain by $0.045 \mathrm{~kg}$ or $19.23 \%$ compared to two-breed crosses, which was statistically confirmed $(\mathrm{P}<0.01)$.

Present results are consistent with research results obtained by Lanza et al. (1984) who have studied production performance of Pinzirita breed and crosses 
with Texel and Ile de France, and established that crosses of $F_{1}$ generation have realized average daily gain of $0.237 \mathrm{~kg}$. Also, Petrović et al. (1995), by comparing the systems of crossing, have stated that three-breed crosses (PxWxIDF), compared to $(\mathrm{PxW})$, to the age of 90 days, have realized by $21.12 \%$ higher daily gain. Use of Ile de France rams in systems of crossing as terminal breed, influenced the increase of body mass of lambs-crosses by 12\% (Boujenane et al., 1998). Positive biological effect of three-breed crossing is consequence of the heterosis effect. The essence of this phenomenon is associated with biochemical and physiological condition of the sheep organism (Bozkov et al., 1980; Andersen and Christensen, 1981; Petrović et al., 1996). It has been established that interracial crossing of sheep significantly influences the stimulation of biosynthetic processes which is manifested through: increased mitochondrial activity, more stable metabolic processes and greater activity of tissue ferments. Experimental study of a group of Russian authors (Sanikov and Kazanovskij, 1981; Selkin et al., 1995) revealed that the activity of aspartate-aminotransferase in lambs-crosses was higher in average by $19.8 \%$ and of alanin-aminotransferase by $16.4 \%$. As concluded by above mentioned authors, this indicates the connection between the level of activity of ferments and daily gain of crossbred lambs.

Heterosis effect occurs in all systems of crossing, but not in the same extent. In case of crossing of two sheep breeds, only the heterosis of the individual animal is exhibited, whereas in three-breed crossing, $100 \%$ heterosis of the individual animal and $100 \%$ heterosis of one of the parents are utilized.

Table 2. Production performance of trial lambs

\begin{tabular}{|l|c|c|}
\hline Parameter & \multicolumn{2}{|c|}{ System of crossing } \\
\cline { 2 - 3 } & PxW & PxWxIDF \\
Number of animals & 30 & 30 \\
Initial body mass, kg & $18.02 \pm 1.22$ & $18.3 \pm 1.19$ \\
Initial age, days & 60 & 60 \\
Final body mass, kg & $29.37 \pm 1.53$ & $32.19^{* *} \pm 1.39$ \\
Final age, days & 120 & 120 \\
Average daily gain, g & $0.189 \pm 0.58$ & $0.234^{* *} \pm 0.46$ \\
\hline
\end{tabular}

** $(\mathrm{P}<0.01)$

(PxW) Pirot Pramenka x Wurttemberg

(PxWxIDF) Pirot Pramenka x Wurttemberg x Il de France 
Results of the comparison of three-breed and two-breed crosses, from the aspect of consumption and utilization of food and nutrients are presented in Tables 3 and 4. By analysing the data presented in Table 3, it can be concluded that crosses PxWxIDF consumed slightly less DM (by 5.19\%) compared to PxW crosses.

Table 3. Consumption of food and nutrients of the diet

\begin{tabular}{|l|c|c|}
\hline \multirow{2}{*}{ Parameter } & \multicolumn{2}{|c|}{ System of crossing } \\
\cline { 2 - 3 } & PxW & PxWxIDF \\
\hline Hay, g/day & 0.271 & 0.237 \\
Concentrate mixture, g/day & 0.625 & 0.614 \\
DM, g/day & 0.790 & 0.749 \\
Total protein, g/day & 0.127 & 0.120 \\
PDIN, g/day & 87.06 & 83.01 \\
PDIE, g/day & 82.99 & 79.46 \\
NEM MJ & 5.84 & 5.61 \\
\hline
\end{tabular}

In regard to food conversion ratio, it is apparent that three-breed crosses used by $29.61 \%$ less hay and by $20.82 \%$ less concentrate mixture compared to twobreed crosses. Our results are consistent with results of (Rodriguez et al.,2011) who have stated that crosses of Merino x Asaf have used by 17\% less DM compared to Asaf lambs. Also, Petrović et al. (1995), who have studied the effects of various crossing combinations: Pirot Pramenka x Merinolandschaf, Pirot Pramenka x Ile de France, Pirot Pramenka x Merinolandschaf $x$ Ile de France and Pirot improved sheep $\mathrm{x}$ Ile de France, in the period before weaning (90 days of age), concluded that crosses products of three-breed crossing have utilized by $17.40 \%$ less concentrate mixture per kilogram of gain, compared to two-breed crosses. More favourable food conversion ratio in three-breed crosses is consequence of positive heterosis effect.

This is confirmation of the conclusions made by Shrestha et al. (2004) claiming that crossing represents economically efficient procedure with aim to utilize individual heterosis and heterosis of the dam.

Table 4. Consumption of food and nutrients per unit of gain

\begin{tabular}{|l|c|c|}
\hline \multirow{2}{*}{ Parameter } & \multicolumn{2}{|c|}{ System of crossing } \\
\cline { 2 - 3 } & PxW & PxWxIDF \\
\hline Hay, g/day & 1.79 & 1.26 \\
Concentrate mixture, g/day & 4.13 & 3.27 \\
DM, g/day & 5.21 & 3.99 \\
Total protein, g/day & 843 & 642 \\
PDIN, g/day & 575 & 443 \\
PDIE, g/day & 548 & 424 \\
NEM MJ & 38.58 & 29.92 \\
\hline
\end{tabular}




\section{Conclusion} concluded:

Based on conducted research and obtained results, the following can be

- Three-breed crosses, in comparison to two-breed crosses, in the fattening period from age of 60 to 120 days, have realized higher gain by $19.23 \%$ $(\mathrm{P}<0.01)$.

- In regard to food conversion ratio, three-breed crosses used by $29.61 \%$ less hay and by $20.82 \%$ less concentrate mixture per $\mathrm{kg}$ of gain, compared to two-breed crosses.

- In comparison of crosses obtained in the system of two-breed (PxW) and three-breed (PxWxIDF) crossing, the three-breed crosses were superior which opens the perspective for more efficient utilization of our sheep breeding population in production of high quality lamb meat.

\section{Acknowledgment}

Research was financed by the Ministry of Education, Science and Technological Development, Republic of Serbia, project TR 31053.

\section{Uticaj sistema ukrštanja na tovne parametre odlučene jagnjadi}

D. Ružić-Muslić, M. P. Petrović, M. M. Petrović, Z. Bijelić, V. Pantelić, P. Perišić, V. Caro-Petrović

\section{Rezime}

U radu je ispitivan uticaj različitih sistema ukrštanja ovaca: dvorasnog $(\mathrm{PxW}) \mathrm{i}$ trorasnog (PxWxIDF), na rezultate u pogledu mase tela i prosečnog dnevnog prirasta jagnjadi zalučene sa 60 dana i tovljene do 120 dana uzrasta. Takođe su praćeni efekti ukrštanja na konzumiranje i konverziju hrane i hranljivih materija. Istraživanja su obavljena na eksperimentalnoj farmi ovaca Instituta za stočarstvo Beograd-Zemun, a za ukrštanje su korišćene sledeće rase ovaca: pirotska pramenka (P), virtemberg (W) i Il de frans (IDF). 
Rezultati su pokazali da su trorasni melezi u odnosu na dvorasne, $\mathrm{u}$ tovu od 60. do 120. dana uzrasta ostvarili za $19.23 \%$ veći prirast i za $5.19 \%$ manje konzumiranje hrane.

U pogledu konverzije hrane, po kg prirasta su utrošili za $29.61 \%$ manje sena i za $20.82 \%$ manje koncentrata.

Pozitivan biološki efekat koji se ispoljio kod meleza (PxWxIDF) je posledica korišćenja heterozisa individue i heterozisa majke.

\section{References}

ANDERSEN E., CHRISTENSEN K. (1981): Physiological explanations of heterosis, 32 nd Annual Meeting of EAAP, 31 August- 5 September, Zagreb

BOZKOV A.I. SERESEVSKA C.M. MAVTINUK H.M. (1980): Sintez nukleinovih kislot $\mathrm{i}$ belkov $\mathrm{v}$ pečeni kris raznih linij $\mathrm{v}$ zavisi mosti ot vozrasta. Biohemija, 45,1,113.

BOUJENANE J., BERRADA D., MIHI S., JAMAI M. (1998): Reproductive performance of ewes and preweaning growth of lambs from three native Moroccan breeds mated to rams from Moroccan and improved breeds. Small Ruminant Research, Volume 27, Issue 3, Pages 203-208.

CHRESTHA J.N.B., HEANEY D.P. (2004): Review Canadian, Outaouais and ridean Arcott breeds of cheep: 2.Crossbreeding registration and subsequent release to the Canadian sheep. Small Ruminant Research. Volume 55, Issues 1-3, pages 1-13.

FARID A. (1991): Slaughter and carcass characteristics of three fattahled sheep breeds and their crosses with Corriedale and Targhee rams. Small Ruminant Research, Volume 5, Issue 3, Pages 255-271.

INRA (1988). Alimentation des bovins, ovins et caprins. Ed. R. Jarriqe,

INRA, Paris, p. 471

LANZA A., ALEO C., LICITRA G., D'AMIGO S., SHIES, L . (1984): Incrocio di prima generazione in allevamenti di pecore Pinzirite con impiego di arieti Ile de France, Texel, Merinolandchaf e Barbareschi. Estratto da Tecnica Agricola n. 4Anno XXXVI

OBRAČEVIĆ Č. (1990): Tables of nutritive value of livestock feed in the diet of ruminants, Scientific Book, Beograd.

PETROVIĆ, P.M., NEGOVANOVIĆ D., ŽUJOVIĆ M. (1995): Nove mogućnosti povećanja proizvodnje jagnjećeg mesa primenom metoda ukrštanja. IV Međunarodni simpozijum: Novi pravci razvoja stočarstva. Biotehnologija u stočarstvu, god. 11, 3-6, Beograd

PETROVIĆ P.M., VLAHOVIĆ M., ŽUJOVIĆ M., NEGOVANOVIĆ D., MEKIĆ C., RUŽIĆ D. (1996): Neki aspekti biohemijske osnove heterozisa kod ovaca.

Biotehnologija u stočarstvu, god. 12, 3-4, pages 67-73, Beograd PETROVIC P.M. (2000): Genetika i oplemenjivanje ovaca. Naučna, Beograd, 365 
RODRIGUEZ A.B., BODAS R., LANDA R., LOPEZ-CAMPOS O., MANTECON A.R., GIRALDEZ F.J. (2011): Animal performance, carcass traits and meat characteristics of Assaf and Merinox Assaf growing lambs. Livestock Science, volume 138, Issues 1-3, pages 13-19

SANIKOV M.I., KAZANOVSKIJ S.A. (1981): Biohemičeskie osnovi heterozisa u ovec. Naučnije trudi VASHIL, 210-218

SCHOEMAN S.J., WET D.R., BOTHA M.A., VAN DER MERWE C.A. (1995): Comparative assessment of biological efficiency of crossbred lambs from two composite lines and Dorper sheep. Small Ruminant Research, Volume 16, Issue 1, Pages 61-67

SELKIN I.I., ČIŽOVA L.N., RABOČEV V.K. (1995): Selekcija ovec na sovemennom etape. Međunarodnij simpozijum. Biotehnologija u stočarstvu, god. 11, 3-6, pages 55-60.

StatSoft, Inc. (data analysis software system), version 6 (2003)

www.statsoft.com.

Received 14 August 2012; accepted for publication 20 September 2012 